\title{
Nose size indicates maximum penile length
}

Hiroshi Ikegaya ${ }^{1 *} \mathbb{D}$, Motofumi Suzuki ${ }^{2,3}$, Hiroki Kondou', Taketo Kawai ${ }^{3}$, Yusuke Sato $^{3}$, Tadaichi Kitamura ${ }^{3}$ and Haruki Kume ${ }^{3}$

\begin{abstract}
Background: In a previous report, we investigated whether the size of male genitalia similarly exposed to serum testosterone during aging could change with age and found that penile length almost stopped increasing during adolescence and decreased in older males. In this report, to determine what factors other than age are related to penile length, we performed a multivariate analysis of the relationships between stretched penile length (SPL) and other measurements of genital organs, nose size, height and body weight in 126 adults in their 30s-50s.

Results: The most highly correlated factor with SPL was flaccid penile length $(r=0.565, P<0.0001)$. The next highest correlation was nose size $(r=0.564, P<0.0001)$. The penile stretched rate correlated with FPL $(r=-0.690$, $P<0.0001$ ) but not with SPL or penile circumference.

Conclusions: The fact that nose size is related to SPL indicates that penile length may not be determined by age, height or body weight but has already been determined before birth.
\end{abstract}

Keywords: Stretched penile length, Nose size, Aging, Cadaver

\section{Résumé}

Contexte: Dans un précédent article, nous avons examiné si la taille des organes génitaux masculins exposés de façon similaire à la testostérone sérique pendant l'avancement en âge pourrait changer avec l'âge; nous avons constaté que la longueur du pénis avait presque cessé d'augmenter à la période de l'adolescence et avait diminué chez les hommes plus âgés. Pour déterminer quels facteurs autres que l'âge étaient liés à la longueur du pénis, nous avons réalisé, dans la présente étude, une analyse multivariée des relations entre la longueur du pénis étiré (LPE) et d'autres mesures des organes génitaux, de la taille du nez, de la taille et du poids corporels chez 126 adultes âgés de 30 à 50 ans.

Résultats: Le facteur le plus fortement corrélé avec la longueur du pénis étiré était la longueur du pénis flasque $(r=0.565, p<0.0001)$. La corrélation suivante la plus élevée était la taille du nez $(r=0,564, p<0,0001)$. Le taux d'étirement du pénis était corrélé à la longueur du pénis étiré $(r=-0.690, p<0.0001)$ mais n'était corrélé ni à la longueur du pénis flasque ni à la circonférence du pénis.

Conclusions: Le fait que la taille du nez soit liée à longueur du pénis étiré indique que la longueur du pénis peut (Continued on next page)

\footnotetext{
*Correspondence: ikegaya-tky@umin.ac.jp; ikegaya@koto.kpu-m.ac.jp

'Department of Forensics Medicine, Graduate School of Medicine, Kyoto

Prefectural University of Medicine, Kajii-cho 465, Kawaramachi-Hirokoji,

Kamigyo-ku, Kyoto 602-8566, Japan

Full list of author information is available at the end of the article
}

C C The Author(s). 2021 Open Access This article is licensed under a Creative Commons Attribution 4.0 International License, which permits use, sharing, adaptation, distribution and reproduction in any medium or format, as long as you give appropriate credit to the original author(s) and the source, provide a link to the Creative Commons licence, and indicate if changes were made. The images or other third party material in this article are included in the article's Creative Commons licence, unless indicated otherwise in a credit line to the material. If material is not included in the article's Creative Commons licence and your intended use is not permitted by statutory regulation or exceeds the permitted use, you will need to obtain permission directly from the copyright holder. To view a copy of this licence, visit http://creativecommons.org/licenses/by/4.0/. The Creative Commons Public Domain Dedication waiver (http://creativecommons.org/publicdomain/zero/1.0/) applies to the data made available in this article, unless otherwise stated in a credit line to the data. 
(Continued from previous page)

ne pas être déterminée par l'âge, la taille ou le poids corporels, mais qu'elle a déjà été déterminée avant la naissance.

Mots-clés: Longueur du Pénis étiré , Taille du Nez, Vieillissement , Cadavre

\section{Background}

Many unidentified dead bodies are discovered every day, not just from acts of terrorism and natural disasters, and this is becoming a major problem worldwide [1]. In Japan, with a population of 120 million, approximately 1000 people are discovered annually as unidentified cadavers, and the police are required to investigate these cases.

In their initial investigations of unidentified corpses, the police seek to identify them using factors, such as age and gender, as well as by their belongings. These dead bodies are often thought to be skeletons or highly decayed. However, in fact, most of them are recently deceased.

Gender is relatively easy to determine by assessing the genitals or DNA examination. However, it is very difficult to estimate age based on cadaver appearance.

Recently, some researchers reported the utility of computed tomography (CT) images for age estimation, especially for the living or nonskeletonized corpses $[2,3]$. However, a body must be transported to obtain CT images, which requires time and effort and incurs costs.

We previously reported that postmortem serum prostate-specific antigen (PSA) level and prostate volume correlate with age and discussed the use of PSA in an objective age estimation [4].

The age-related increase in serum PSA levels has been attributed mainly to prostate enlargement due to prolonged exposure to serum testosterone during aging [5-7]. Testosterone is also related to the growth of the penis in newborn infants [8].

Therefore, we also investigated whether the size of the male genitalia similarly exposed to serum testosterone during aging could change with age in our previous report. We found that penile length almost stopped increasing during adolescence, remained unchanged in middle age, and decreased slightly in older males [9]. The saying "Big nose, big hose" suggests that nose size indicates penile length. However, scientific reports that prove this statement are not available to date.

In this report, to confirm the truth of this statement, we analyzed the relationships between stretched penile length (SPL) and nose size as well as the weight of male genital organs in middle-aged people.

\section{Materials and methods}

One hundred twenty-six male forensic autopsy cases at Kyoto Prefectural University of Medicine from April
2015 to March 2019 were used in this study. All cases were in their $30 \mathrm{~s}-50 \mathrm{~s}$, and their postmortem time was within 3 days. Height, weight, SPL, flaccid penile length (FPL), penile circumference (PC), right and left testicular weights, prostate weight, and nose size were measured at the autopsy by one researcher during the period. SPL was measured by manual traction [10]. SPL was measured at room temperature, which was maintained at $22^{\circ} \mathrm{C}$, with the cadaver lying in the supine position and the penis placed at a $90^{\circ}$ angle to the body. The nose size was defined as the longer distance between the midpoint of the left and right medial ocular angles and the outside of the left or right nose wings (Fig. 1).

This study was approved by the Institutional Review Board of Kyoto Prefectural University of Medicine (ERBC-1491-1).

\section{Statistical analysis}

Relationships among age, height, body weight and factors related to the genital organs were analyzed using Pearson's linear correlation. To identify independent predictive factors influencing SPL, multivariate analyses were performed using linear regression models. Analysis was performed using JMP software (SAS Institute Inc., Cary, NC).

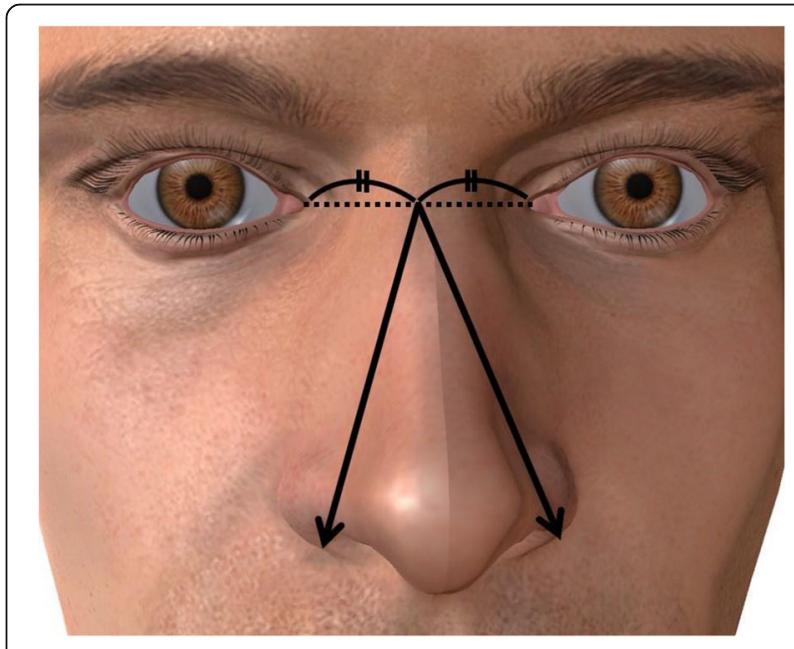

Fig. 1 The measurement of nose size. Nose size was defined as the longer distance between the midpoint of the left and right medial ocular angles and the outside of the left or right nose wings (indicated by arrow) 
Table 1 Relationships among age, height, body weight and factors related to genital organs (multivariate analysis using linear regression models)

\begin{tabular}{|c|c|c|c|c|c|c|c|c|c|c|}
\hline & Body weight & Height & Left testis weight & Right testis weight & Prostate weight & Flaccid penile length & Stretched penile length & Penile stretched rate & Penile circumference & Nose size \\
\hline Age & $\begin{array}{l}r=-0.270 \\
p=0.003\end{array}$ & $\begin{array}{l}r=0.0 .128 \\
p=0.1725\end{array}$ & $\begin{array}{l}r=0.252 \\
p=0.0064\end{array}$ & $\begin{array}{c}r=0.226 \\
p=0.0145\end{array}$ & $\begin{array}{c}r=0.015 \\
p=0.8727\end{array}$ & $\begin{array}{c}r=0.133 \\
p=0.1558\end{array}$ & $\begin{array}{c}r=0.057 \\
p=0.5437\end{array}$ & $\begin{array}{l}r=0.103 \\
p=0.2729\end{array}$ & $\begin{array}{l}r=0.094 \\
p=0.3163\end{array}$ & $\begin{array}{l}r=-0.057 \\
p=0.5428\end{array}$ \\
\hline Body weight & & $\begin{array}{c}r=0.424 \\
p<0.0001\end{array}$ & $\begin{array}{c}r=0.524 \\
p<0.0001\end{array}$ & $\begin{array}{c}r=0.441 \\
p<0.0001\end{array}$ & $\begin{array}{l}r=0.260 \\
p=0.0045\end{array}$ & $\begin{array}{l}r=0.156 \\
p=0.0948\end{array}$ & $\begin{array}{l}r=0.018 \\
p=0.8465\end{array}$ & $\begin{array}{c}r=0.145 \\
p=0.1216\end{array}$ & $\begin{array}{c}r=0.034 \\
p=0.7132\end{array}$ & $\begin{array}{c}r=0.244 \\
p=0.0083\end{array}$ \\
\hline Height & & & $\begin{array}{l}r=0.296 \\
p=0.0012\end{array}$ & $\begin{array}{c}r=0.262 \\
p=0.0045\end{array}$ & $\begin{array}{l}r=0.076 \\
p=0.419\end{array}$ & $\begin{aligned} r & =0.090 \\
p & =0.3374\end{aligned}$ & $\begin{array}{c}r=0.191 \\
p=0.0397\end{array}$ & $\begin{array}{c}r=0.026 \\
p=0.7794\end{array}$ & $\begin{array}{l}r=0.024 \\
p=0.796\end{array}$ & $\begin{array}{c}r=0.378 \\
p<0.0001\end{array}$ \\
\hline Left testis weight & & & & $\begin{array}{c}r=0.883 \\
p<0.0001\end{array}$ & $\begin{array}{c}r=0.375 \\
p<0.0001\end{array}$ & $\begin{array}{l}r=0.033 \\
p=0.7284\end{array}$ & $\begin{array}{l}r=0.101 \\
p=0.283\end{array}$ & $\begin{array}{c}r=0.117 \\
p=0.2122\end{array}$ & $\begin{aligned} r & =0.008 \\
p & =0.9352\end{aligned}$ & $\begin{array}{c}r=0.287 \\
p=0.0018\end{array}$ \\
\hline Right testis weight & & & & & $\begin{array}{l}r=0.390 \\
p<0.0001\end{array}$ & $\begin{array}{l}r=0.010 \\
p=0.9128\end{array}$ & $\begin{array}{c}r=0.085 \\
p=0.3656\end{array}$ & $\begin{array}{l}r=0.075 \\
p=0.421\end{array}$ & $\begin{array}{l}r=0.043 \\
p=0.648\end{array}$ & $\begin{array}{r}r=0.268 \\
p=0.0036\end{array}$ \\
\hline Prostate weight & & & & & & $\begin{array}{c}r=0.124 \\
p=0.1834\end{array}$ & $\begin{array}{c}r=0.090 \\
p=0.3392\end{array}$ & $\begin{array}{l}r=0.052 \\
p=0.5763\end{array}$ & $\begin{array}{c}r=0.103 \\
p=0.2699\end{array}$ & $\begin{aligned} r & =0.212 \\
p & =0.0225\end{aligned}$ \\
\hline Flaccid penile length & & & & & & & $\begin{array}{c}r=0.565 \\
p<0.0001\end{array}$ & $\begin{array}{l}r=0.690 \\
p<0.0001\end{array}$ & $\begin{array}{l}p=-0.049 \\
p=0.6025\end{array}$ & $\begin{aligned} r & =0.228 \\
p & =0.0137\end{aligned}$ \\
\hline Stretched penile length & & & & & & & & $\begin{aligned} r & =0.170 \\
p & =0.0674\end{aligned}$ & $\begin{array}{l}r=-0.108 \\
p=0.247\end{array}$ & $\begin{array}{r}r=0.564 \\
p<0.0001\end{array}$ \\
\hline Penile stretched rate & & & & & & & & & $\begin{array}{l}r=0.046 \\
p=0.6215\end{array}$ & $\begin{array}{r}r=0.213 \\
p=0.0215\end{array}$ \\
\hline Penile circumference & & & & & & & & & & $\begin{aligned} r & =0.009 \\
p & =0.9245\end{aligned}$ \\
\hline
\end{tabular}

$r$ Pearson correlation coefficient. $p$ Dark gray-hatched cells represent $p<0.010$ ). Gray cells indicate $p<0.050$ )

\section{Results}

Table 1 presents the relationships among age, height, body weight and factors related to the genital organs.

The most highly correlated factors were stretched penile length and flaccid penile length $(r=0.565, p<0.0001)$. The next highest correlation was noted for stretched penile length and nose size $(r=0.564, p<0.0001)$. The penile stretch rate was highly correlated with the flaccid penile length $(r=-0.690, p<0.0001)$ but not with the stretched penile length or penile circumference. Nose size was correlated with all factors except penile circumference: height $(r=0.378, P=0.083)$, body weight $(r=0.378$, $P<0.0001)$, left testis $(r=0.287, p<0.0018)$, right testis $(r=0.268, \quad p=0.004)$, prostate weight $(r=0.212, p=$
0.0225), flaccid penile length $(r=0.228, p=0.137)$ and nose size. Body weight was highly correlated with height $(r=0.424, p<0.0001)$, left testis $(r=0.524, p<0.0001)$, right testis $(r=0.441, p<0.0001)$, prostate weight $(r=$ $0.260, p=0.0045)$ and nose size but not with stretched penile length, flaccid penile length or penile circumference. Age was weakly correlated with body weight $(r=-$ $0.270, p=0.003)$, left testis $(r=-0.252, p=0.0064)$ and right testis $(r=-0.226, p=0.0145)$.

The linear regression model is presented in Fig. 2. The relationship between stretched penile length and nose size is presented in Table 2. The average stretched penile length gradually increased in the longer nose size groups.

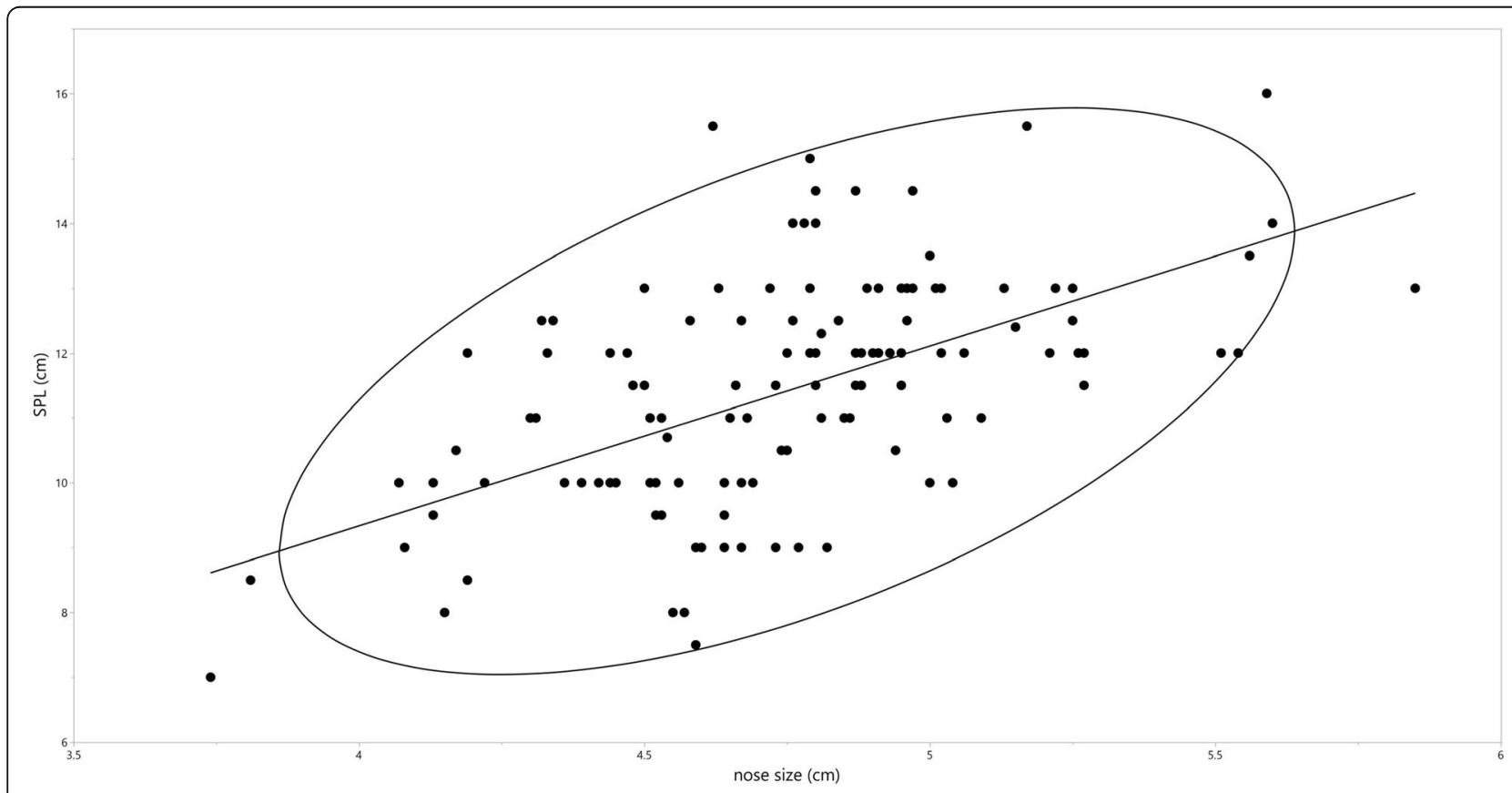

Fig. 2 Linear regression analysis of stretched penile length and nose size. SPL: stretched penile length 
Table 2 Relationship between nose size and stretched penile length

\begin{tabular}{llll}
\hline Nose size $(\mathbf{c m})$ & $\mathbf{n}$ & Average SPL $(\mathbf{c m})$ & SD \\
\hline-4.50 & 27 & 10.37 & 1.56 \\
$4.51-5.00$ & 75 & 11.40 & 1.77 \\
$5.01-5.50$ & 18 & 12.33 & 1.16 \\
$5.51-$ & 6 & 13.42 & 1.50 \\
\hline
\end{tabular}

SPL Stretched penile length, SD Standard deviation, $n$ Number

\section{Discussion}

In our study, nose size was not correlated with factors related to body physiques but was correlated with SPL. In previous reports, embryonic androgens and androgen receptors were associated with penile growth $[11,12]$. Penile growth is also consistent with SPL being associated with the second to fourth digit ratio, which has been linked to androgen exposure [13]. In the field of forensic medicine, it is widely known that the size of the skull, excluding the jawbone, is relatively unaffected by aging. Similar to the SPL, as a representative measurement of head parts, nose size may be also not determined by age or body size but has already been determined before birth.

Our study also suggests that SPL and nose size can be used as indicators independent of age and postnatal body size.

As expected, a significant correlation was found between SPL and FPL. This finding is attributed to the fact that a person with a longer FPL may naturally have a longer SPL given the flexibility of penile tissue. Contrary to our data, showing that FPL was negatively correlated with penile stretched rate would suggest that the individual had a different penile extension rate. The same result was also noted in another report [13]. The elasticity of a small, flaccid penis may be greater than that of a large, flaccid penis.

In contrast to SPL, a weak correlation with nose size was found with FPL $(r=0.228, p=0.0137)$. This finding may be attributed to the fact that the contraction rate of the penis varies slightly based on FPL in contrast to SPL, which indicates the maximum length during erection. In addition, the absence of blood flow in the cadavers contributed to the variation in the measured values of FPL.

A high second to fourth digit ratio may indicate a small penis [13]. In addition, there is a report that a high second to fourth digit ratio may indicate small testes [14]. In addition, a correlation may exist between testis weight and nose size. Unfortunately, we did not analyze the second to fourth digits in our present study. Only weak correlations were noted between left and right testis weights and nose size in our study.

Although our results are useless for forensic purposes, understanding the growing process of the penis or facial features may be very important for extrapolating fetal androgen levels and following male genital functions. This study is the first to demonstrate the relationship between SPL and nose size but is limited in Japanese male cadavers, and the reason why SPL and nose size are related is still unclear. Therefore, we consider it an interesting subject to pursue from now on.

\section{Conclusions}

Nose size was highly related to stretched penile length in Japanese male cadavers.

\section{Abbreviations}

BMI: Body mass index; CT: Computed tomography; FPL: Flaccid penile length; PC: Penile circumference; PSA: Prostate-specific antigen; SPL: Stretched penile length

\section{Acknowledgments}

Not applicable.

\section{Authors' contributions}

Conception and design: Suzuki M, Kitamura T and Ikegaya H. Drafting of manuscript: Ikegaya $\mathrm{H}$ and Suzuki M. Acquisition of data: Ikegaya $\mathrm{H}$ and Kondou $\mathrm{H}$. Analysis and interpretation of data: Ikegaya $\mathrm{H}$ and Kondou $\mathrm{H}$. Obtaining funding: Ikegaya $\mathrm{H}$. Statistical analysis: Ikegaya $\mathrm{H}$. Administrative, technical, or material support: Suzuki M. Supervision: Kitamura T. and Kume $\mathrm{H}$. Critically reviewed the manuscript for important intellectual content: Kawai T., Sato Y., Kitamura T. and Kume H. All authors approved the final version of the manuscript and agree to be accountable for all aspects of the work in ensuring that questions related to the accuracy or integrity of any part of the work are appropriately investigated and resolved.

\section{Funding}

This research received no external funding.

\section{Availability of data and materials}

The datasets generated during and/or analyzed during the current study are available from the corresponding author on reasonable request.

\section{Ethics approval and consent to participate}

The study was approved by the Institutional Review Board of Kyoto Prefectural University of Medicine (ERB-C-1491-1).

\section{Consent for publication}

Informed consent was obtained from legal guardians.

\section{Competing interests}

The authors declare that they have no competing interests.

\section{Author details}

${ }^{1}$ Department of Forensics Medicine, Graduate School of Medicine, Kyoto Prefectural University of Medicine, Kajii-cho 465, Kawaramachi-Hirokoji, Kamigyo-ku, Kyoto 602-8566, Japan. Department of Urology, Tokyo Metropolitan Bokutoh Hospital, 4-23-15 Kotobashi, Sumida-ku, Tokyo 130-8575, Japan. ${ }^{3}$ Department of Urology, Graduate School of Medicine, The University of Tokyo, 7-3-1 Hongo, Bunkyo-ku, Tokyo 113-8655, Japan.

Received: 20 July 2020 Accepted: 11 January 2021

Published online: 04 February 2021

\section{References}

1. Cattaneo C, Ritz-Timme S, Schutz HW, Collins M, Waite E, Boormann H, et al. Unidentified cadavers and human remains in the EU: an unknown issue. Int J Legal Med. 2000;113(3):N2-3 Epub 2000/07/06.

2. Hocaoglu E, Inci E, Ekizoglu O, Steyn M, Uys A. Age estimation in the living: cervical ring apophysis development in a Turkish sample using CT. Int J Legal Med. 2020;134(6):2229-37 Epub 2020/08/12. 
3. Monum T, Makino Y, Prasitwattanaseree S, Yajima D, Chiba F, Torimitsu S, et al. Age estimation from ossification of sternum and true ribs using 3D post-mortem CT images in a Japanese population. Leg Med (Tokyo). 2020; 43:101663 Epub 2020/01/20.

4. Tsuboi H, Miyamori D, Ishikawa N, Ichioka H, Ikegaya H. Relationship between serum prostate-specific antigen and age in cadavers. SAGE Open Med. 2020;8:2050312120958212.

5. Collins GN, Lee RJ, McKelvie GB, Rogers AC, Hehir M. Relationship between prostate specific antigen, prostate volume and age in the benign prostate Br J Urol. 1993;71(4):445-50 Epub 1993/04/01.

6. Kirollos MM. Statistical review and analysis of the relationship between serum prostate specific antigen and age. J Urol. 1997;158(1):143-5 Epub 1997/07/01.

7. Oesterling JE, Kumamoto Y, Tsukamoto T, Girman CJ, Guess HA, Masumori $\mathrm{N}$, et al. Serum prostate-specific antigen in a community-based population of healthy Japanese men: lower values than for similarly aged white men. Br J Urol. 1995;75(3):347-53 Epub 1995/03/01.

8. Kareem AJ, Elusiyan JBE, Kareem AO. Stretched penile length and total serum testosterone in term male neonates. Pan Afr Med J. 2020;37:61 Epub 2020/11/28

9. Suzuki M, Ikegaya H, Idota N, Kawai T, Sato Y, Kume H. Penile size and stretched rate in a Japanese male population: a cross-sectional cadaveric study. Int J Urol. 2019;26(9):936-7 Epub 2019/07/16.

10. Davoudzadeh EP, Davoudzadeh NP, Margolin E, Stahl PJ, Stember DS. Penile length: measurement technique and applications. Sex Med Rev. 2018;6(2): 261-71 Epub 2018/01/01

11. Baskin LS, Sutherland RS, DiSandro MJ, Hayward SW, Lipschutz J, Cunha GR. The effect of testosterone on androgen receptors and human penile growth. J Urol. 1997;158(3 Pt 2):1113-8 Epub 1997/09/01.

12. Byne W. Developmental endocrine influences on gender identity: implications for management of disorders of sex development. Mt Sinai Med. 2006;73(7):950-9 Epub 2007/01/02

13. Choi $\mathrm{H}$, Kim KH, Jung H, Yoon SJ, Kim SW, Kim TB. Second to fourth digit ratio: a predictor of adult penile length. Asian J Androl. 2011;13(5):710-4 Epub 2011/07/05.

14. Oh JK, Kim KT, Yoon SJ, Kim SW, Kim TB. Second to fourth digit ratio: a predictor of adult testicular volume. Andrology. 2014;2(6):862-7 Epub 2014/ 08/15.

\section{Publisher's Note}

Springer Nature remains neutral with regard to jurisdictional claims in published maps and institutional affiliations.

Ready to submit your research? Choose BMC and benefit from:

- fast, convenient online submission

- thorough peer review by experienced researchers in your field

- rapid publication on acceptance

- support for research data, including large and complex data types

- gold Open Access which fosters wider collaboration and increased citations

- maximum visibility for your research: over $100 \mathrm{M}$ website views per year

At $\mathrm{BMC}$, research is always in progress.

Learn more biomedcentral.com/submissions 